FERNALD, R. (Max-Planck-Institut für Psychistrie, Abteilung Neurophysiologie 8 Müchen 23, Kraeplinstr. 2, Germany), \& CHASE, R. An improved method for plotting retinal landmarks and focusing the eyes. Vision Research, $1971,11,95-96$.

FISHER, G. H. (University of Newcastle, Newcastle upon Tyne, NE1 7RU, England). Geometrical illusions and figural after-effects: The mechanism and its location. Vision Research, 1971, 11, 289-309.

FOSTER, D. H. (Applied Optics Group, Physics Department, Imperial College, London, S.W.7, England). The response of the human visual system to moving spatially-periodic patterns: Further analysis. Vision Research, 1971, 11, 57.81 .

GIESSMANN, H.-G. \& LUTZE, B. Die c-inflexion in der dunkeladaptationskurve. Vision Research, 1971, 11, 343-350.

KULIKOWSKI, J, J. (Physiological Laboratory, Cambridge CB2 3EG, England). Some stimulus parameters affecting spatial and temporal resolution of human vision. Vision Research, 1971, 11, 83-93.

NEWSOME, D. A. (Ophthalmology Branch, National Eye Institute, National Institutes of Health, U.S. Department of Health, Education, and Welfare, Bethesda, Md. 20014). Afterimage and pupillary activity following strong light exposure. Vision Research, 1971, 11, 275-288.

PRESTRUDE, A. M. (Virginia Polytechnic Institute, Blacksburg. Va. 24061), \& BAKER, H. D. Light adaptation and visual latency. Vision Research, 1971, 11, 363-369.

REGAN, D. (Department of Communication, University of Keele, Keele, Staffordshire, England), \& TYLER, C. W. Wavelength-modulated light generator. Vision Research, 1971, $11,43-56$.

ROHLER, R. (Institut für med. Optik der Universität, Barbarastr. 16, Müchen 13, Germany), \& FISCHER, W. Influence of waveguide modes on the light absorption in photoreceptors. Vision Research, 1971, 11, 97-101.
RUDDOCK, K. H. (Applied Optics Section, Physics Department Imperial College, South Kensington, London S.W.7, England). Parafoveal colour vision responses of four dichromats. Vision Research, 1971, $11,143 \cdot 156$

SHCHADRIN, V. E. (Institute of Problems of Information Transmission, Academy of Sciences of the USSR, Moscow, USSR), \& BONGARD, M. M. A new type of lateral interaction in the human visual system. Vision Research, 1971, 11, 241-249.

VALBERG, A. (Laboratorium für Farbenmetrik, Physikalisches Institut der Universität Basel, Switzerland). A method for the precise determination of achromatic colours including white. Vision Research, 1971, 11, 157-160.

WRIGHT, P. (Medical Research Council, Applied Psychology Unit, Cambridge University, Cambridge, England), \& KAHNEMAN, D. Evidence for alternative strategies of sentence retention. Quarterly Journal Experimental Psychology, 1971, 23, 197-213.

\title{
CURRENT LITERATURE ON HUMAN VISION
}

ALLAN, L. G. (McMaster University, Hamilton, Ontario, Canada), KRISTOFFERSON, A. B., \& WIENS, E. W. Duration discrimination of brief light flashes. Perception \& Psychophysics, 1971, $9,327-334$.

ANDERSON, D. E. (University of Oregon Medical School, Portland, Oreg. 97201). Border contrast as a function of retinal locus. Perception \& Psychophysics, 1971, 9, 105-109.

BJORK, E. L. (University of Michigan, Ann Arbor, Mich. 41804), \& ESTES, W. K. Detection and placement of redundant signal elements in tachistoscopic displays of letters. Perception \& Psychophysics, 1971, 9, 439-442.

DOCKSTADER, S. L. (Denver University, Denver, Colo. 80210). Comparison of cupulometric and psychophysical thresholds for perception of rotation and the oculogyral illusion. Perception \& Psychophysics, 1971, 9, 299-302.

LINK, S. W. (McMaster University, Hamilton, Ontario, Canada), \&
TINDALL, A. D. Speed and accuracy in comparative judgments of line length. Perception \& Psychophysics, 1971, 9, 284-288.

ONO, H. (York University, Toronto, Ontario, Canada), KOMODA, M., \& MUELLER, E. R. Intermittent stimulation of binocular disparate colors and central color fusion. Perception \& Psychophysics, 1971, 9, 343-347.

POLLACK, I. (Mental Health Research Institute, University of Michigan, Ann Arbor, Mich. 41804). Perception of two-dimensional Markov constraints within visual displays. Perception \& Psychophysics, 1971, 9, 461-464.

RUBINSTEIN, L. (Psychiatric Epidemiology Research Unit, 722 West 168th Street, New York, N.Y. 10032), \& GRUENBERG, E. M. Intramodal and crossmodal sensory transfer of visual and auditory temporal patterns. Perception \& Psychophysics, 1971, 9, 385-390.

SEKULER, R. (Northwestern University, Evanston, Ml. 60201),
LEHR, D., STONE, W., \& WOLF, M. Human visual motion sensitivity: Evidence against a ratio theory of sensory coding. Perception \& Psychophysics, 1971, 9, 483-484.

UTTAL, W. R. (University of Michigan, Ann Arbor, Mich. 41804). A masking approach to the problem of form perception. Perception \& Psychophysics, 1971, 9, 296-298.

VIRSU, V. (University of Helsinki, Helsinki $17, \quad$ Finland). Underestimation of curvature and task dependence in visual perception of form. Perception \& Psychophysics, 1971, 9, 339-342.

WELCH, R. B. (University of Kansas, Lawrence, Kans. 66044). Prism adaptation: The "target-pointing effect" as a function of exposure trials. Perception \& Psychophysics, 1971, 9, 102-104.

ZUSNE, L. (University of Tulsa, Tulsa, Okla. 74104). Measures of symmetry. Perception \& Psychophysics, 1971, 9, 363-366. 
AIKEN, L. S. (Temple University, Philadelphia, $\mathrm{Pa}, 19122), \&$ BROWN, D. Feature utilization of continuously varying attributes in visual pattern classification. Perception \& Psychophysics, 1971, 9, 145-149.

BERNSTEIN, I. H. (University of Texas at Arlington, Arlington, Tex. 76010), \& CLARK, M. H. Intersensory effects in the psychological refractory period. Perception \& Psychophysics, 1971, 9, 135-139.

COLTHEART, M. (University of Waterloo, Waterloo, Ontario, Canada). The effect of verbal size information upon visual judgments of absolute distance. Perception \& Psychophysics, 1971, 9, 222-223.

DEWAR, R. (University of Calgary, Calgary 44, Alberta, Canada). Adaptation to displace vision: $\mathrm{V}$ a r i a $\mathrm{i}$ on $\mathrm{s}$ on $\mathrm{th}$ e "prismatic-shaping" technique. Perception \& Psychophysics, 1971, $9,155 \cdot 157$.

FAW, T. T. (University of California,
Los Angeles, Calif. 90024), \& NUNNALLY, J. C. The influence of stimulus incongruity on the familiarity effect in visual selection. Perception \& Psychophysics, 1971, 9, 150-154.

GOLDSTEIN, A. G. (University of Missouri, Columbia, Mo. 65201), \& CHANCE, J. E. Visual recognition memory for complex configuration. Perception \& Psychophysics, 1971, 9, 237-241.

HALE, S. M., \& SIMPSON, H. M. (Carleton University, Ottawa, Ontario, Canada). Effects of eye movements on the rate of discovery and the vividness of visual images. Perception \& Psychophysics, 1971, 9, 242-246.

KINCHLA, R. A. (Princeton University, Princeton, N.J. 08540). Visual movement perception: A comparison of absolute and relative movement discrimination. Perception \& Psychophysics, 1971, 9, 165-171.

MATTHEWS, M. L. (University of Guelph, Guelph, Ontario, Canada).
A study of afterimages generated by monocular and dichoptic viewing. Perception \& Psychophysics, 1971, 9, 225-226.

PRESSEY, A. W. (University of Manitoba, Winnipeg, Manitoba, Canada). An extension of assimilation theory to illusions of size, area, and direction. Perception \& Psychophysics, 1971, 9, 172-176. SIEGEL, M. H. (Albion College, Albion, Mich. 49224), \& SIEGEL, A. B. Color name as a function of surround luminance and stimulus duration. Perception \& Psychophysics, 1971, 9, 140-144.

VIRSU, V. (University of Helsinki, Helsinki, Finland). Tendencies to eye movement, and misperception of curvature, direction, and length. Perception \& Psychophysics, 1971, 9, 65-72.

WOLL, S. (University of Illinois, Urbana, ll. 61820), ERIKSEN, C. W., \& HAKE, H. W. A forced-choice study of edge detectors in the human visual system. Perception \& Psychophysics, 1971, 9, 247-252.

\section{CURRENT LITERATURE ON HUMAN VISION}

ABRAVANEL, E. (George Washington University, Washington, D.C. 20006). The synthesis of length within and between perceptual systems. Perception \& Psychophysics, 1971, 9, 327-328.

$\mathrm{BEH}, \mathrm{H}$. C. (University of Sydney, Sydney, Australia), WENDEROTH, P. M., \& PURCELL, A. T. The angular function of a rod-and-frame illusion. Perception \& Psychophysics, 1971, 9, 353-355.

BOWER, T. G. R. (University of Edinburgh, Scotland), BROUGHTOn, J. M., \& MOORE, M. K. Infant responses to approaching objects: An indicator of response to distal variables. Perception \& Psychophysics, 1971, 9, 193-196.

DORNBUSH, R. L. Delay of auditory input in "simultaneous" auditory and visual short-term memory. Perception \& Psychophysics, 1971, 9, 97.98.

FLOCK, H. R. (York University,
Downsview, Ontario, Canada). Achromatic surface color and the direction of illumination. Perception \& Psychophysics, 1971, 9, 187-192.

FRIEDMAN, M. P. (University of California at Los Angeles, Los Angeles, Calif. 90024), REED, S. K., \& CARTERETTE, E. C. Feature saliency and recognition memory for schematic faces. Perception \& Psychophysics, 1971, 10, 47-50.

HAINES, R. F. (Ames Research Center, NASA Moffett Field, Calif. $94035)$. The retinal threshold gradient in the presence of a high-luminance target and in total darkness. Perception \& Psychophysics, 1971, 9, 197-202.

LaBERGE, D. (University of Minnesota, Minneapolis, Minn. 55455 ). On the processing of simple visual and auditory stimuli at distinct levels. Perception \& Psychophysics, 1971, 9, 331-334.

LEE, D. N. (University of Edinburgh,
Edinburgh, Scotland). Binocular stereopsis without spatial disparity. Perception \& Psychophysics, 1971, 9, 216-218.

SHIPLEY, T. (Bascom Palmer Eye Institute, University of Miami School of Medicine, Miami, Fla. 33136), \& RAWLINGS, S. C. Sensory direction in homogeneous binocular visual space. Perception \& Psychophysics, 1971, 9, 335-337.

SPERLING, G. (Bell Telephone Laboratories, Murray Hill, N.J. 07974 ). Information retrieval from two rapidly consecutive stimuli: $A$ new analysis. Perception \& Psychophysics, 1971, 9, 89-91.

THIJSSEN, J. M. (Laboratory of Physics, Department of Ophthalmology, Nijmegen University, Nijmegen, The Netherlands), \& VENDRIK, A. J. H. Differential luminance sensitivity of the human visual system. Perception \& Psychophysics, 1971, 10, 58-64. 
BERRY, C. (North East London Polytechnic, London, England). Advanced frequency information and verbal response times. Psychonomic Science, 1971, 23, 151-152.

BOUSFIELD, W. A. (University of Connecticut, Storrs, Conn. 06268), ABRAMCZYK, R. R., \& STEIN, D. $K$. The effects of synonymity on item recall and sequential ordering in multitrial free recall. Psychonomic Science, 1971, 23, 173-175.

BOWEN, J. H. (State University of New York at Albany, Albany, N.Y. 12203). The stability of the printed frequencies of occurrence of 420 English conceptual nouns. Psychonomic Science, 1971, 23, $156-158$.

EVANS, D. R. (Department of Educational Psychology, University of Calgary, Calgary 44, Alberta, Canada). Paragraph complexity, arousal, and subjective evaluations of attractiveness. Psychonomic Science, 1971, 23, 303-304.

GOSS, A. E. (Rutgers-The State
University, Douglass College, New Brunswick, N.J. 08903). Formation, maintenance, generalization, and retention of response hierarchies: Persistence of differences due to meaningfulness of response members. Psychonomic Science, $1971,23,271.272$.

HANEY, J. N. (Norristown State Hospital, Norristown, Pa. 19401), BRUNING, J. L., \& NOSIN, J. The effects of disorganizing cues on the utilization of a mnemonic structure. Psychonomic Science, 1971, 23, $167-168$

MANDLER, G. (University of California, San Diego, La Jolla, Calif. 92037). Storage and retrieval in a paired-associate task. Psychonomic Science, 1971, 23, 298-299.

McGUIGAN, F. J. (Hollins College, Roanoke, Va. 24020), \& TANNER, R. G. Covert oral behavior during conversational and visual dreams. Psychonomic Science, 1971, 23, 263-264.

MILLER, S. M. (Towson State College, Baltimore, Md. 21204), \&
WEINSTOCK, R. B. Memory span and intralist response similarity in paired-associate learning. Psychonomic Science, 1971, 23, 139-140.

SHINE, D. (Fordham University, New York, N.Y. 10458), \& WALSH, J. $F$. Developmental trends in the use of logical connectives. Psychonomic Science, 1971, 23, 171-172.

SOLSO, R. L. (Loyola University of Chicago, Chicago, Ill. 60626). Meaningfulness of colors. Psychonomic Science, 1971, 23, 301-303.

WILSON, W. H., \& NUNN ALLY, J. C. (Vanderbilt University, Nashville, Tenn. 37203). A naturalistic investigation of acquired meaning in children. Psychonomic Science, 1971, 23, 149-150.

YOSHIMURA, E. K., MOELY, B. E. (University of Hawaii, Honolulu, Hawaii 96822), \& SHAPIRO, S. I. The influence of age and presentation order upon children's free recall and learning to learn. Psychonomic Science, 1971, 23, 261-263.

\section{CURRENT LITERATURE ON VERBAL PROCESSES}

AIKEN, E. G. (Naval Personnel and Training Research Laboratory, San Diego, Calif. 92152). Linguistic and imaginal mnemonics in paired-associate recall. Psychonomic Science, 1971, 24, 91-93.

ALLEN, D. V. (Department of Audiology, Wayne State University, Detroit, Mich. 48202). Modality of similarity and hearing ability. Psychonomic Science, 1971, 24, 69-71.

CUNNINGHAM, M. (Murray State University, Murray, Ky. 42071), \& CRADY, C. A. Identification of olfactory dimensions by semantic differential technique. Psychonomic Science, 1971, 23, 387-388.

DALE, H. C. A. (University of Hull, Hull, England), \& McGLAUGHLIN, A. Evidence of acoustic coding in long-term memory Quarterly Journal of Experimental Psychology, 1971, 23, 1-7.

D'AMATO, M. F. (Brooklyn College, Brooklyn, N.Y. 11210), \& RUGGER, K. Semantic and associative factors in transfer. Psychonomic Science, 1971, 23, 399-400.
HEALY, A. F. (Rockefeller University, New York, N.Y. 10021), \& MILLER, G. A. The relative contribution of nouns and verbs to sentence acceptability and comprehensibility. Psychonomic Science, 1971, 24, 94-95.

KENNEDY, R. A. (University of Dundee, Dundee, Scotland), \& WILKES, A. L. Functional structure in sentences: A performance analysis. Quarterly Journal of Experimental Psychology, 1971, 23, 214-224.

LINDLEY, R. E. (California State College, Fullerton, Calif. 92634), \& BROWN, D. R. Acoustic and associative coding in short-term memory. Quarterly Journal of Experimental Psychology, 1971, 23, 14-21.

LOCKE, J. L. (Children's Research Center, Champaign, IIl. 61820). Phonetic mediation in four-year-old children. Psychonomic Science, 1971, 23, 409 .

MARTIN, J. E. (Pennsylvania State University, University Park, $\mathrm{Pa}$. 16802), \& MOLFESE, D. Some developmental aspects of preferred adjective ordering. Psychonomic Science, 1971, 22, 219-220.

PAIVIO, A. (University of Western Ontario, London, Ontario, Canada), \& CSAPO, K. Short-term sequential memory for pictures and words. Psychonomic Science, 1971, 24, 50-51.

RUSSELL, E. P. (Rutgers-The State University, New Brunswick, N.J. 08903), \& GOSS, A. E. Retroactive inhibition of preexperimentally established associations through 24 hours. Psychonomic Science, 1971, 23, 393-395.

SMALLWOOD, R. A. (University of Richmond, Richmond, Va. 23173), \& TROMATER, L. J. Acoustic interference with redundant elements. Psychonomic Science, 1971, 22, 354-357.

WARD, L. C. (Murray State University, Murray, Ky. 42071), \& SIEGEL, P. S. Effects of delay of reinforcement and stimulus meaningfulness on the discrimination learning of retardates at two intelligence levels. Pscyhonomic Science, 1971, 23, 395-396. 


\section{CURRENT LITERATURE ON VERBAL PROCESSES}

ANDERSON, N. H. (University of California, La Jolla, Calif, 92037). Two more tests against change of meaning in adjective combinations. Journal of Verbal Learning \& Verbal Behavior, 1971, 10, 75-85.

BEGG, I. (University of Western Ontario, London 72, Ontario, Canada). Recognition memory for sentence meaning and wording. Journal of Verbal Learning \& Verbal Behavior, 1971, 10, 176-181.

CAIRNS, H. S. (University of Texas at Austin, Austin, Tex. 78712), \& FOSS, D. J. Falsification of the hypothesis that word frequency is a unified variable in sentence processing. Journal of Verbal Learning \& Verbal Behavior, 1971, 10, 41-43.

CLAY, M. M. (University of Auckland, Auckland, New Zealand), \& IMLACH, R. H. Juncture, pitch, and stress as reading behavior variables. Journal of Verbal Learning \& Verbal Behavior, 1971, $10,133-139$.
DANKS, J. H., \& GLUCKSBERG, S. (Princeton University, Princeton, N.J. 08540). Psychological scaling of adjective orders. Journal of Verbal Learning \& Verbal Behavior, $1971,10,63-67$.

DUKE, A. W. (University of Nebraska, Lincoln, Nebr. 68508). Children's retention of a single item as a function of acoustic similarity to interfering items. Journal of Verbal Learning \& Verbal Behavior, 1971, $10,13-22$.

KAPLAN, I. T. (New York University Medical Center, New York, N.Y. 10016), CARVELLAS, T., \& METLAY, W. Effect of context on verbal recall. Journal of Verbal Learning \& Verbal Behavior, 1971, $10,207-212$

KLANK, L. J. K. (University of Colorado, Boulder, Colo. 80302). HUANG, Y., \& JOHNSON, R. C. Determinants of success in matching word pairs in tests of phonetic symbolism. Journal of Verbal Learning \& Verbal Behavior, 1971, $10,140-148$.
NURSS, J. R. (Georgia State University, Atlanta, Ga. 30303), \& D A Y, D. E. Imitation, comprehension, and production of grammatical structures. Journal of Verbal Learning \& Verbal Behavior, $1971,10,68-74$.

PALERMO, D. S. (Pennsylvania State University, University Park, Pa. 16802), \& PARRISH, M. Rule acquisition as a function of number and frequency of exemplar presentation. Journal of Verbal Learning \& Verbal Behavior, 1971, 10, 44-51.

SHAPIRO, S. I. (University of Hawaii, Honolulu, Hawaii 96822), \& GORDON, G. P. Contemporary norms of word and phonetic frequencies. Journal of Verbal Learning \& Verbal Behavior, 1971, 10, 92-94.

WOOD, G. (Michigan State University, East Lansing, Mich. 48823). Organization, large memory units, and free recall. Journal of Verbal Learning \& Verbal Behavior, 1971, $10,52-56$.

\section{CURRENT LITERATURE ON VERBAL PROCESSES}

d'ANGLEJAN, A. (McGill University, Montreal 110 , P.Q., Canada), LAMBERT, W. E., TUCKER, G. R., \& GREENBERG, J. H. Psychological correlates of the French sound system. Perception \& Psychophysics, 1971, 9, 356-357.

DICK, A. O. (University of Rochester, Rochester, N.Y. 14627). Processing time for naming and categorization of letters and numbers. Perception \& Psychophysics, 1971, 9, 350-352.

FILLENBAUM, S. (University of North Carolina, Chapel Hill, N.C. 27514). Syntactic locus as a determinant of judged pause duration. Perception \& Psychophysics, 1971, 9, 219-221.

FILLER, J. W. (Wake Forest University, Winston-Salem, N.C. 27106), \& WILLIAMS, J.E. Conditioning the connotative meanings of color names to human figures. Perceptual \& Motor Skills, $1971,32,755-763$.
McGINLEY, H. (University of Wyoming, Laramie, Wyo. 82070). Relationship between denotative and connotative meaning as an intrasubject phenomenon. Perceptual \& Motor Skills, 1971, 32, 207-211.

SHEVRIN, H. (Department of Research, The Menninger Foundation, Topeka, Kans.66601), SMITH, W.H., \& FITZLER, D.E. Average evoked response and verbal correlates of unconscious mental processes. Psychophysiology, 1971, 8, 149-162.

STEPHENS, B. (Temple University, Philadelphia, Pa. 19122), \& McLAUGHLIN, J.A. Analysis of performance by normals and retardates of Piagetian reasoning assessments as a function of verbal ability. Perceptual \& Motor Skills, $1971,32,868-870$.

STRANGE, W. (University of Minnesota, Minneapolis, Minn.
55455), \& HALWES, T. Confidence ratings in speech perception research: Evaluation of an efficient technique for discrimination testing. Perception \& Psychophysics, 1971, 9, 182-186.

TOWNSEND, J. T. (Purdue University, West Lafayette, Ind. 47907). Theoretical analysis of an alphabetic confusion matrix. Perception \& Psychophysics, 1971, 9, 40-50.

TREISMAN, A. M. (Department of Experimental Psychology, South Parks Road, Oxford, England), \& FEARNLEY, S. Can simultaneous speech stimuli be classified in parallel? Perception \& Psychophysics, 1971, 10, 1-7.

WARREN, R. M. (University of Wisconsin-Milwaukee, Milwaukee, Wis. 53201), \& OBUSEK, C. J. Speech perception and phonemic restorations. Perception \& Psychophysies, 1971, 9, 358-362. 


\section{CURRENT LITERATURE ON VERBAL PROCESSES}

BADDELEY, A. D. (Experimental Psychology, Laboratory, University of Sussex, Brighton BN1 9QY, Sussex, England). Language habits, acoustic confusability, and immediate memory for redundant letter sequences. Psychonomic Science, 1971, 22, 120-121.

BRYANT, E. (Saint Louis University, St. Louis, Mo. 63103), \& O'CONNELL, D. A phonemic analysis of nine samples of glossolalic speech. Psychonomic Science, 1971, 22, 81-83.

FILLENBAUM, S. (University of North Carolina, Chapel Hill, N.C. 27514). On coping with ordered and unordered conjunctive sentences. Journal of Experimental Psychology, 1971, 87, 93-98.

FULKERSON, F. E. (Western Illinois University, Macomb, IIl. 61455), \& JOHNSON, J. E. Methodological variables in verbal discrimination learning. Psychonomic Science, 1971, 22, 68-69.

GEFFEN, G. (Monash University, Clayton, Victoria 3168, Australia), BRADSHAW, J. L., \& WALLACE,
G. Interhemispheric effects on reaction time to verbal and nonverbal visual stimuli. Journal of Experimental Psychology, 1971, 87, 415-422.

GUMENIK, W. E. (University of Toledo, Toledo, Ohio 43606), \& DOLINSKY, $R$. Effect of verb and object meaning on the connotative evaluation of sentence subjects. Journal of Experimental Psychology, 1971,87, 436-438.

KROSSNER, W. J. (Fordham University, Bronx, N.Y. 10458). Further evidence for linguistic operations in the analysis of class-membership statements. Psychonomic Science, 1971, 22, 127-128.

POWELL, A. (University of Nebraska, Lincoln, Nebr. 68506), \& VEGA, M. Word association and verbal analogy problems. Psychonomic Science, 1971, 22, 103-104.

ROSEN, S. M. (Staten Island Community College, N.Y. 10301), \& GREENHOUSE, P. The effect of stimulus type on formal similarity between stimuli and their primary associations. Psychonomic Science, 1971, 22, 66-67.

ROWE, E. J. (University of Western Ontario, London 72, Ontario, Canada), \& PAIVIO, A. Discrimination learning of pictures and words. Psychonomic Science, $1971,22,87-88$.

SCHWARTZ, M. (University of Wisconsin, Madison, Wis. 53706). S u b.ject-generated versus experimenter-supplied mediators in paired-associate learning. Journal of Experimental Psychology, 1971, 87, 389-395.

TULVING, E. (Yale University, New Haven, Conn. 06510), \& THOMSON, D. M. Retrieval processes in recognition memory: Effects of associative context. Journal of Experimental Psychology, 1971, 87, 116-124.

WEARING, A. J. (Yale University, New Haven, Conn. 06510). Vividness in the recall of English nominalizations. Psychonomic Science, 1971, 22, 121-122.

\section{CURRENT LITERAURE ON VERBAL PROCESSES}

GAERTNER, S. L. (University of Delaware, Newark, Del. 19711), \& SEIDENBERG, B. Familiarity and value effects upon stereoscopic work recognition. Perceptual \& Motor Skills, 1971, 32, 703-708.

JUST, M. A. (Stanford University, Stanford, Calif. 94305), \& C A R P E N T E R, P. A. Comprehension of negation with quantification. Journal of Verbal Learning \& Verbal Behavior, 1971, 10, 244-253.

POLLACK, I. (Mental Health Research Institute, University of Michigan, Ann Arbor, Mich. 41804). Temporal anagrams: Word identification with successively presented letters in scrambled order. Perception \& Psychophysics, 1971. 9, 430-434.

TAPLIN, J. E. (University of Adelaide, South Australia 5001, Australia).
Reasoning with conditional sentences. Journal of Verbal Learning \& Verbal Behavior, 1971, 10, 291-225.

VON WRIGHT, J. M. (University of Turku, Turku, Finland). Effects of distributed practice and distributed recall tests on later recall of paired associates. Journal of Verbal Learning \& Verbal Behavior, 1971, 10, 311-315.

WICHAWUT, C. (University of Michigan, Ann Arbor, Mich. 48104 ), \& MARTIN, E. Independence of $A-B$ and $A-C$ associations in retroaction. Journal of Verbal Learning \& Verbal Behavior, 1971, 10, 316-321.

WINGFIELD, A. (Brandeis University, Waltham, Mass. 02154), \& KLEIN, J. F. Syntactic structure and acoustic pattern in speech perception. Perception \&
Psychophysics, 1971, 9, 23-25.

WOLLEN, K. A. (Washington State University, Pullman, Wash. 99163), \& LOWRY, D. H. Effects of imagery on paired-associate learning. Verbal Learning \& Verbal Behavior, 1971, 10, 276-284.

ZAKIA, R. D. (Rochester Institute of Technology, Rochester, N.Y. 14623), \& HABER, R. N. Sequential letter and word recognition in deaf and hearing subjects. Perception \& Psychophysics, 1971, 9, 110-114.

ZELNIKER, T. (Tel-Aviv University, Ramat-Aviv, Tel-Aviv, Israel). Perceptual attenuation of an irrelevant auditory verbal input as measured by an involuntary verbal response in a selective-attention task. Journal of Experimental Psychology, 1971, 87, 52-56. 
CERMAK, L. S. (Tufts University, Medford, Mass. 02155), \& LEVINE, R. Encoding as a function of the presentation-rehearsal interval in short-term memory. Psychonomic Science, 1971, 23, 423-424.

DALE, H. C. A. (University of Hull, Hull, England), \& McGLAUGHLIN, A. Evidence of acoustic coding in long-term memory. Quarterly Journal of Experimental Psychology, 1971, 23, 1-7.

D'AMATO, M. F. (Brookly n College, Brooklyn, N.Y. 11210), \& RUGGER, K. Semantic and associative factors in transfer. Psychonomic Science, 1971, 23, 399.400.

DARWIN, C. J. (University of Connecticut, Storrs, Conn. 06268). Ear differences in the recall of fricatives and vowels. Quarterly Journal of Experimental Psychology, 1971, 23, 46-62.

KAHNEMAN, D. (Hebrew University, Jerusalem, Israel), \& WRIGHT, P. Changes of pupil size and rehearsal strategies in a short-term memory task. Quarterly Journal of Experimental Psychology, 1971, 23,
187-196.

KENNEDY, R. A. (University of Dundee, Dundee, Scotland), \& WILKES, A. L. Functional structure in sentences: A performance analysis. Quarterly Journal of Experimental Psychology, 1971, 23, 214-224.

LEVY, B. A., \& BADDELEY, A. (University of Sussex, Sussex BN1, England). Recall of semantic clusters in primary memory. Quarterly Journal of Experimental Psychology, 1971, 23, 8-13.

LINDLEY, R. E. (California State College, Fullerton, Calif. 92634), \& BROWN, D. R. Acoustic and associative coding in short-term memory. Quarterly Journal of Experimental Psychology, 1971, 23, 14-21.

PERFETTI, C. A. (Learning Research and Development Center, University of Pittsburgh, Pittsburgh, Pa. 15213), \& GOODMAN, D. Memory for sentences and noun phrases of extreme depth. Quarterly Journal of Experimental Psychology, 1971, 23, 22.33.

PETRUSIC, W. M. (Carleton
University, Ottawa, Ontario, Canada), \& HINDS, B. Long-term mediational processes in short-term memory. Behavior Research Methods \& Instrumentation, 1971, 3, 183-185.

RUSSELL, E. P. (Rutgers-The State University, New Brunswick, N.J. 08903), \& GOSS, A. E. Retroactive inhibition of preexperimentally established associations through 24 hours. Psychonomic Science, 1971, 23, 393-395.

WINEFIELD, A. H. (University of Adelaide, Adelaide, Australia), \& JEEVES, M. A. The effect of overtraining on transfer between tasks involving the same stimulus dimension. Quarterly Jourmal of Experimental Psychology, 1971, 23, 234-242.

WRIGHT, P. (Medical Research Council, Applied Psychology Unit, Cambridge, Cambridge, England), \& KAHNEMAN, D. Evidence for alternative strategies of sentence retention. Quarterly Journal of Experimental Psychology, 1971, 23, 197-213.

\section{CURRENT LITERATURE ON HUMAN MEMORY}

BOLT, M. (Calvin College, Grand Rapids, Mich. 49506). Imagery in associative learning and memory. American Journal of Psychology, $1971,84,246-252$.

DAMIANOPOULOS, E. N. (University of Iowa, Iowa City, Iowa 52240). Stimulus and response availability in associative learning. American Journal of Psychology, 1971, 84, 12-22.

DELPRATO, D. J. (Eastern Michigan University, Ypsilanti, Mich. 48197). Specific-pair interference on recall and associative-matching retention tests. American Journal of Psychology, 1971, 84, 185-193.

JOHNSON, G. J. (University of British Columbia, Vancouver, British Columbia, Canada). Transfer as a function of paradigm and interspersed-pair difficulty. American Journal of Psychology, $1971,84,276-287$.

MARTIN, E. (University of Michigan, Ann Arbor, Mich. 48104), \& CAREY, S. T. Retroaction, recovery, and stimulus meaningfulness in the $A \cdot B, A-B r$ paradigm. American Journal of Psychology, 1971, 84, 123-133.

McCABE, L. (University of Southern California, University Park, Los Angeles, Calif. 90007), \& MADIGAN, S. Negative effects of recency in recall and recognition. Journal of Verbal Learning \& Verbal Behavior, 1971, 10, 307-310.

SASSON, R. Y. (Laboratoire de Psychologie expérimental de la Sorbonne, 28 rue Serpente, 75 Paris 6 , France). Semantic organizations and memory for related sentences. American Journal of Psychology, $1971,84,253-267$.

SLAK, S. (University of Toledo, Toledo, Ohio 43606). Univariate and bivariate information storage. American Journal of Psychology, 1971, 84, 205-209.

TEGHTSOONIAN, R. (Smith College, Northampton, Mass. 01060), \& TEGH T SOONIA N, M.
Discontinuities in recognition learning revealed by critical-trial analy sis. American Journal of Psychology, 1971, 84, 75-84.

TURNAGE, T. W. (University of Maryland, College Park, Md. 20742), \& STEINMETZ, J. I. Unit-sequence interference and short-term recall. American Journal of Psychology, 1971, 84, 112-122.

WOOD, L. E. (University of Iowa, Iowa City, Iowa 52240), \& HINRICHS, J. V. Cuing of recall order in immediate memory with different rates of presentation. American Journal of Psychology, 1971, 84, 268-275.

WORTMAN, P. M. (Duke University, Durham, N. C. 27706), \& GREENBERG, L. D. Coding, Recoding, and decoding of hierarchical information in long-term memory. Journal of Verbal Learning \& Verbal Behavior, $1971,10,234-243$. 


\section{CURRENT LITERATURE ON HUMAN SOMESTHESIS AND CHEMICAL SENSES}

ABRAVANEL, E. (George Washington Univeraity, Washington, D.C. 2006). The syntheses of length within and between perceptual systems. Perception \& Psychophysics, 1971 , 9, 327-328

CABANAC, M. (Université Claude Bernard, U. E. C. Médicale Lyon Sud-Ouest, B. P. 12, 69, Oullins, France), CUNNINGHAM, D. J., \& S T O L W I J K, J. A. J. Thermoregulatory set point during exercise: A behavioral approach. Journal of Comparative \& Physiological Psychology, 1971, 76, $94 \cdot 102$.

CALTHEN, N. R. (University of Georgia, Athens, Ga. 30601), \& BOARDMAN, W. K. Body boundary and stimulus enhancement, Perceptual \& Motor Skills, 1971, 32, 559-563.

COMALLI, P. E. (Temple University, Philadelphia, Pa. 19122), \& ALTSHULER, M. W. Effect of body tilt on auditory localization. Perceptual \& Motor Skills, 1971,
32, $723-726$.

CUNNINGHAM, II. (Murray State University, Murray, Ky. \$2071), \& CRADY, C. A. Identification of olfactory dimensions by semantic differential technique. Psychonomic Science, 1971, 23, 387-388.

DOCKSTADER, S. L. (San Jose State College, San Jose, Calif. 95100). Comparison of cupulometric and psychophysical thresholds for perception of rotation and the oculogyral illusion. Perception \& Psychophysics, 1971, 9, 299-000.

CARMON, A., \& FINGER, S. (Washington Liniversity, St. Louis, Mo. 63130). Spatial and temporal interaction in tactile adaptation. Perceptual \& Motor Skills, 1971, $32,427-433$.

HENION, K. E. (University of Texas, A ustin, Tex. 78712 ). Psychophysical scales of the olfactory pleasantness of homologous alcohols. Perception \& Psychophysics, 1971, 9, 234-236,

MEISELMAN, H. L. (U.S. Army
Natick Laboratories, Natick, Mass. 01760). Effect of presentation procedure on taste intensity functions. Perception \& Psychophysics, 1971, 9, 15-18.

RUGG, E. A. (Florida Presbyterian College, St. Petersburg, Fla. 33733), \& MACDOUGALL, J. M. Effects of excessive temperature change on contrast in temperae perception. Psychonomic Science, 1971, 23, $267-268$.

von BEKESY, G. (Laboratory of Sensory Sciences, University of Hawaii, Honolulu, Hawaii 96822). Localization of visceral pain and other sensations before and after anesthesia. Perception \& Psychophysics, 1971. 9, 1-4.

VERRILLO, R. T. (Laboratory of Sensory Communication, Syracuse, N.Y. 13210 ). Vibrotactile thresholds measured at the finger. Perception \& Psychophysics, 1971, 9, 329-330.

\section{CLRRENT LITERATURE ON PREFERENCE}

COOMBS, C. H. (University of Michigan, Ann Arbor, Mich. 48104), \& BOWEN, J. Additivity of risk in portfolios. Perception \& Psychophysics, 1971, 9, 43-46.

FORD, M. P. (California Department of Mental Hygiene, Pacific State Hospital, Pomona, Calif. 91768). Serial position preferences in children in simultaneous vs successive matching tasks. Perceptual \& Motor Skills, 1971, $32,963-968$.

GELLER, E. S. Virginia Polytechnic Institute and State University, Blacksburg, Va. 24061 ), WHITMAN, C. P., \& BEAMON, W. $S$. Effects of expressed and measured value preference on decision speed. Psychonomic Science, 1971, 23, 84-86.

HINTZ, J. M. (University of Alberta, Edmonton, Alberta, Canada), \& Nelson, T. M. Haptic aesthetic value of the golden section. British Journal of Psychology, 1971, 62, $217-233$.

JONES, Q. R. (Columbus College,
Columbus, Ga. 31907), \& MOYEL, I. $S$. The influence of iris color and pupil size on expressed affect. Psychonomic Science, 1971, 23, 126-127.

LEE, W. (1393E Solano Ave., AJbany, $C$ alif. 94706). The effects of expected value difference and expected regret ratio on preference strength. American Journal of Psychology, 1971, 84, 194-204.

MARTIN, J. E. (Pennsylvania State Lniversity, University Park, $\mathrm{Pa}$. 16802), \& MOLFESE, D. Some developmental aspects of preferred adjective ordering. Psychonomic Science, 1971, 23, 219-220

PAYNE, J. W., \& BRAUNSTEIN, M. L. (School of Social Sciences, University of California, Irvine, Calif. 92664). Preferences among gambles with equal underlying distributions. Journal of Experimental Psychology, 1971, 87, 13:18.

R O U B E R T O X, P. (Institit d'esthetique et des sciences de l'art. University of Paris, 75 -Paris. 5eme,
France), CARLIER, M., \& CHAGUIBOFF, J. Preference for non-objective art: Personal and psychological determiners. British Journal of Psychology, 1971, 62, 105-110.

SCHILLACE, R. (Oakland University, Rochester, Mich. 48063), \& DRAGAN, E. Affect and acquisition: List learning of nouns as a function of like-dislkie ratings. Psychonomic Science, 1971, 23, $52-54$.

SINGH, D. (University of Texas, Austin, Tex.78712), \& QUERY, W. $T$. Preference for work over "freeloading" in children. Psychonomic Science, 1971, 23, 77-79.

STEVENSON, A. H. (Department of Applied Behavioral Sciences, University of California, Davis, Calif. 95616), \& LYNN, D. B. Preference for high variability in young children. Psychonomic Science, 1971, 23, 143-144. 
BURNS, M. M., \& MOSKOWITZ, H. (Institute of Transportation and Traffic Engineering, University of California, Los Angeles, Calif 90024). Response time to a first signal as: a function of time relationship to a second signal and mode of presentation. Perceptual \& Motor Skills, 1971, 32, 811-816.

C AIN, W. S. (John B. Pierce Foundation and Yale University, New Haven, Conn. 06520), \& STEVENS, J. C. Effort in sustained and phasic handgrip contractions. American Journal of Psychology, $1971,84,52-65$.

CLEMENT, D. E. (University of South Florida, Tampa, Fla. 33620), \& SCHIERECK, J. J. Scanning strategies and differential sensitivity in a visual signal detection task: Intersubject consistency. Psychonomic Science, 1971, 23, 385-387.

DOWNING, B. D. (Kent State University, Kent, Ohio 44240.) Response probabilities and "same-different" reaction times.
Perception \& Psychophysics, 1971, 9, 213-215.

FORD, M. P. (Califorria Department of Mental Hygiene, Pacific State Hospital, Pomona, Calif. 91768). Serial position preferences in children in simultaneous vs successive matching tasks. Perceptual \& Motor Skills, 1971, 32, 963-968.

HENDERSON, L. (University of Guelph, Guelph, Ontario, Canada), \& MATTHEWS, M. L. Perception and memory loss of item and order information in short-term memory. Perception \& Psychophysics, 1971, 9, 231-233

HINES, G. H. (Falcon Management Consultants, Ltd. 10 Dryden Chambers, 119 Oxford St., London W1R, 1PA, England). Effectiveness of social and nonsocial reinforcers in a probability learning task. Psychonomic Science, 1971, 23, 411-413.

MACKAY, D. G. (University of California, Los Angeles, Calif. 90024). Stress preentry in motor systems. American Journal of Psychology, 1971, 84, 35-51.

MAXWELL, W. A., MILLER, F. D., \& MEYER, P. A. (University of South Dakota, Vermillion, S. Dak. 57069). The relationship between punishment and unavoidability in eliminating avoidance behavior in humans. Psychonomic Science, $1971,23,435-436$.

SANFORD, A. J. (The University, Dundee DD $14 \mathrm{HN}$, Angus, Scotland), \& MAULE, J. A. Age and the distribution of observing responses. Psychonomic Science, 1971, 23, 419-420.

SMITH, N. C. (Ohio State University, Columbus, Ohio 43210). Long-term retention of a pursuitmeter skill. Perceptual \& Motor Skills, 1971, $32,773.774$.

TOLIN, P. (Central Washington State College, Ellensburg, Wash. 98926). Instruction effects on watch keeping in a "simple" vigilance task. Perception \& Psychophysics, 1971, 9, 227-228.

\section{CURRENT LITERATURE ON PERFORMANCE}

BERNSTEIN, I. H. (University of Texas at Arlington, Arlington, Tex. 76010), \& CLARK, M. H. Intersensory effects in the psychological refractory period. Perception \& Psychophysics, 1971, 9, 135.139.

BRLIHART, B. L. (University of Nebraska at Omaha, Omaha, Nebr. 68105), \& BRILHART, J. K. Field independence and academic achievement of engineering students. Perceptual \& Motor Skills, $1971,32,443.446$.

DUKE, M. P. (Emory University, Atlanta, Ga. 30322). Reaction time and normetenephrine-metanephrine excretion under intense stimulation in chronic schizophrenics, non-psychotics, and normals. Perceptual \& Motor Skills, 1971, $32,579-586$.

FLOWERS, J. H. (Yale University, New Haven, Conn. 06510), \& GARNER, W. R. The effect of stimulus element redundancy on speed of discrimination as a function of state and process limitation. Perception \& Psychophysics, 1971, 9, 158-160.

FOSS, D. J. (University of Texas at Austin, Austin, Tex. 78712), \& DOWELL, B. E. High-speed memory retrieval with auditorily presented stimuli. Perception \& Psychophysics, 1971, 9, 465-468.

GRILL, D. P. (Johns Hopkins University, Baltimore, Md. 21218). Variables influencing the mode of processing of complex stimuli. Perception \& Psychophysics, 1971, 10, 51-57.

JONES, R. W. (Georgia State University, Atlanta, Ga. 30303), \& TALLARICO, R. B. Effects of rigidity and anxiety on pursuit rotor performance. Perceptual \& Motor Skills, 1971, 32, 227-232.

KEELY, K. (University of Western Australia, Nedlands, Western Australia, Australia). Age and task effects in short-term memory of children. Perception \& Psychophysics, 1971, 9, 480-482.
LONG, G. M. (University of Detroit, Detroit, Mich. 48221), \& Mo, S. S. Interaction of arousal and task difficulty upon perceptual restriction. Perceptual \& Motor Skills, 1971, 32, 259-264.

MORF, M. E. (University of Windsor, Windsor, Ontario, Canada), KA V A N A UG H , R. D., \& McCONVILLE, $M$. Intratest and sex differences on a portable rod-and-frame test. Perceptual \& Motor Skills, 1971, 32, 727-733.

TREISMAN, A. M. (Department of Experimental Psychology, South Parks Road, Oxford, England), \& FEARNLEY, S. Can simultaneous speech stimuli be classified in parallel? Perception \& Psychophysics, 1971, 10, 1-7.

WILKINSON, R. T. (Medical Research Council, Applied Psychology Unit, C a mbridge, England), \& STRETTON, M. Performance after awakening at different times of night. Psychonomic Science, 1971, 23, 283-285. 
ARABIE, P., \& MOSCOVITZ, H. R. (U. S. Army Natick Laboratories, Natick, Mass. 01760). The effect of viscosity upon perceived sweetness. Perception \& Psychophysics, 1971, 9, 410-412.

BAIRD, JC. (Dartmouth College, Hanover, N.H. 03755), KREINDLER, M. \& JONES, K. Generation of multiple ratio scales with a fixed stimulus attribute. Perception \& Psychophysics, 9, 399-403.

BERGLUND, B., BERGLUND, U., ENGEN, T. (Brown University, Providence, R.I. 02912), \& LINDVALL, $T$. The effect of adaptation on odor detection. Perception \& Psychophysics, 1971, 9, 435-438.

BUJAS, Z. (The Rockefeller Unicersity, New York, N.Y. 10012), \& PFAFFMANN, C. Potassium gymnemate and the sweet and bitter taste provoked electrically. Perception \& Psychophysics, 1971, 9, 28-29.

CAIN, W. S. (John B. Pierce Foundation Laboratory, New Haven, Conn. 06519). Physiochemical characteristics and supraliminal odor intensity: Reply to Mitchell. Perception \&
Psychophysics, 1971, 9, 478.479.

DAWSON, W. E. (University of Notre Dame, Notre Dame, Ind, 46556), \& BRINKER, R. P. Validation of ratio scales of opinion by multimodality matching. Perception \& Psychophysics, 1971, 9, 413-417.

ELSNER, $\dot{W}$. (University of Florida College of Medicine, Gainesville, Fla. 32601). Power laws for the perception of rotation and the oculogyral illusion. Perception \& Psychophysics, 1971, 9, 418-420.

HENION, K. E. (University of Texas, A ustin, Tex. 78712 ). Psychophysical scales of the olfactory pleasantness s. Perception \& Psychophysics, 1971, 9, 234-236.

MACLEAN, I. E. (University of Strathclyde, Glasgow, C. 1, Scotland). \& STACEY, B. G. Judgment of angle size: An experimental appraisal. Perception \& Psychophysics, 1971, 9, 449-505.

MEISELMAN, H. L. (U. S. Army, Natick Laboratories, Natick, Mass. 01760). Effect of presentation procedure on taste intensity functions. Perception \& Psychophysics, 1971, 9, 15-18.

MITCHELL, M. J. (University of Canterbury, Christchurch, New Zealand). Olfactory power law exponents and water solubility of odorants: A comment on Cain's (1969) study. Perception \& Psychophysics, 1971, 9, 477 .

POLLACK, I. (Mental Health Research Institute, University of Michigan, Ann Arbor, Mich, 41804). Perception of two-dimensional Markov constraints within visual displays. Perception \& Psychophysics, 1971, 9, 461-464.

SEKULER, R. (Northwestern University, Evanston, Ill. 60201), LEHR, D., STONE, W., \& WOLF, M. Human visual motion sensitivity: Evidence against a ratio theory of sensory coding. Perception \& Psychophysics, 1971, 9, 483-484.

STEVENS, J. C. (John B. Pierce Foundation Laboratory, New Haven, Conn. 06519), \& MARKS, L. Spatial summation and the dynamics of warmth sensation. Perception \& Psychophysics, 1971 , 9, 391-398.

THIJSSEN, J. M. (Laboratory of Physics, Department of Opthalmology, Nijmegen, The Netherlands), \& VENDRIK, J. H. Differential luminance sensitivity of the human visual system. Perception \& Psychophysics, 1971, 9, 58-64.

\section{CURRENT LITERATURE ON PSYCHOPHYSICS}

ALLAN, L. G. (McMaster University, Hamilton, Ontario, Canada), KRISTOFFERSON, A. B., \& WIENS, E. W. Duration discrimination of brief light flashes. Perception \& Psychophysics, 1971, 9, 327-334.

BUCHSBAUM, M. (Laboratory of Mental. Health, National Institutes of Health, Bethesda, Md. 20014), SILVERMAN, J., HENKIN, R. I., \& PFEFFERBAUM, A. Contrast effects on the auditory evoked response and its relation to psychophysical judgments. Perception \& Psychophysics, 1971 , 9, 379-384.

DOCKSTADER, S. L. (San Jose State College, San Jose, Calif. 9510). Comparison of cupulometric and psychophysical thresholds for perception of rotation and the oculogyral illsuion. Perception \& Psychophysics, 1971, 9, 299-302.

AREND, L. E., BUEHLER, J. N., \& LOCKHEAD, G. R. (Duke University, Durham, N.C. 27706). Difference information in brightness perception. Perception \& Psychophysics, 1971, 9, 367-370.

EGETH, H. (The Johns Hopkins University, Baltimore, Md. 21218). Laterality effects in perceptual matching. Perception Psychophysics, 1971, 9, 375-376.

ER LEBACHER, A. (Northwestern University, Evanston, IIl. 60201), \& SEKULER, R. Response frequency equalization: A bias model for psychophysics. Perception \& Psychophysics, $1971,9,315 \cdot 320$.

HAINES, R. (Ames Research Center, NASA Moffet Field, Calif. 94035). The retinal threshold gradient in the presence of a high-luminance target and in total darkness. Perception \& Psychophysics, 1971, 9, 197-202.

HUCKABEE, M. W. (University of Southern Mississippi, Hattiesburg, Miss. 39401). Effects of anchor stimuli on category and ratio scaling. Perceptual and Motor Skills, $1971,32,831-839$.

LEE, D. N. (University of Edinburgh, Edinburgh, Scotland). Binocular stereopsis without spatial disparity. Perception \& Psychophysics, 1971, 9, 216-218

LINK, S. W. (McMaster University, Hamilton, Ontario, Canada), \& TINDALL, A. D. Speed and accuracy in comparative judgments of line length. Perception \& Psychophysics, 1971, 9, 284-288.

O'GORMAN, J. G. (University of Queensland, 4067 Australia).
Latency and habituation of the electrodermal response. Psychophysiology, 1971, 8, 280.

RESTLE, F. (Indiana University, Bloomington, Ind. 47401), \& LEVISON, M. Method of constant stimuli: Invalidity to the third power. Perception \& Psychophysics, $1971,9,312-314$.

SEKULER, R. (Northwestern University, Evanston, Dl. 60201), \& ERLEBACHER, A. The invalidity of "invalid results from the method of constant stimuli": A common artifact in the methods of psychophysics. Perception \& Psychophysics, 1971, 9, 309-311.

STEGER, J. A. (State University of New York at Albany, Albany, N.Y. 12203), \& DE SETTO, L. On the developmental aspects of the range-frequency compromise in judgment. Perceptual and Motor Skills, 1971, 32, 799-802.

TEGHTSOONIAN, R. (Smith College, Northampton, Mass. 01060). On the exponents in Stevens' law and the constant in Ekman's law. Psychological Review, 1971, 78, 71-80. 


\section{CURRENT LITERATURE ON PSYCHOPHYSICS}

ABRAVANEL, E. (The George Washington University, Washington, D.C. 20006). The synthesis of length within and between perceptual systems. Perception \& Psychophysics, 1971, 9, 327-328.

BERGLUNDB. (University of Stockholm, Stockholm, Sweden), BERGLUND, U., EKMAN, G. \& E N G E , T. Individual psychophysical functions for 28 odorants. Perception \& Psychophysics, 1971, 9, 379-384.

BURNSIDE, $W$. (Indiana University, Bloomington, Ind. 47401). Judgment of short time intervals while performing mathematical tasks. Perception \& Psychophysics, $1971,9,404-406$.

CHAPANIS, A: (The Johns Hopkins University, Baltimore, Md. 21218), \& OVERBEY, C.M. Absolute judgments of colors using natural color names. Perception \& Psychophysics, 1971, 9, 356-360.

DAWSON, W. E. (University of Notre Dame, Notre Dame, Ind. 46556). Magnitude estimation of apparent sums and differences. Perception \& Psychophysics, 1971, 9, 368-374.
EGETH, H. (The Johns Hopkins University, Baltimore, Md. 21218), \& BLECKER, D. Differential effects of familiarity on judgments of sameness and difference. Perception \& Psychophysics, 1971, 9, 321-326. GUZY, L. T. (Alliance College, Cambridge Springs, $\mathrm{Pa}$. 16403), \& AXELROD, S. Synchronization of unimanual and bimanual responses with monotic and dichotic clicks. Perception \& Psychophysics, 1971, 9, 161-164.

KERR, J. L. (University of Pittsburgh School of Medicine, Pittsburgh, $\mathrm{Pa}$. 15213). Visual resolution in the periphery. Perception \& Psychophysics, 1971, 9, 375-378.

KIETZMAN, M. L. (Biometrics Research, 722 West 168th St., New York, N.Y. 10032), BOYLE, R. C., \& LINDSLEY, D. B. Perceptual masking: Peripheral vs central factors. Perception \& Psychophysics, 1971, 9, 350-352.

MOSKOWITZ, H. R. (U. S. Army Natick Laboratories, Natick, Mass. 01760). Ratio scales of acid sources. Perception \& Psychophysics, 1971, 9, 371-374.
POLLACK, I. (Mental Helath Research Institute, University of Michigan, Ann Arbor, Mich. 48104). Methodological examination of the PEST (parametric estimation by sequential testing) procedure: II. Perception \& Psychophysics, 1971, 9, 229-230.

RENDLEMAN, P., ROSE, R. M. (University of Washington, Seattle, Wash. 98105), \& TELLER, D. Y. Statistical properties of Pollack's PEST procedure. Perception \& Psychophysics, 1971, 9, 208-212.

VERRILLO, R. T. (Laboratory of Sensory Communication, Syracuse University, Syracuse, N.Y. 13210). Vibrotactile thresholds measured at the finger. Perception \& Psychophysics, 1971, 9, 329-330.

WOLL, S. (University of minois, Urbana, \#l. 61820), ERICKSON, C. W., \& HAKE, H. W. A forced-choice study of edge detectors in the human visual system. Perception \& Psychophysics, 1971, 9, 247-252.

ZUSNE, L. (University of Tulsa, Tulsa, Okla. 74104). Measures of symmetry. Perception \& Psychophysics, 1971, 9, 363-366.

\section{CURRENT LITERATURE ON PSYCHOPHYSICS}

ADAMS, R. M. (Fort Hays Kansas State College, Hays, Kans. 67601). Number as a stimulus in a card-sorting task. Psychonomic Science, 1971, 23, 183-184.

ADOLPH, A. R. (Neurophysiology Laboratory, Retina Foundation, 20 Staniford Street, Boston, Mass. 02114). Discrete slow potentials and threshold-level spikes in the Limulus ommatidium. Vision Research, 1971, 11, 371-376.

A N D ER SON, K. V. (Emory University, Atlanta, Ga. 30322), \& MAHAN, P. E. Increased pain thresholds following combined lesions of thalamic nuclei centrum medianum and centralis lateralis. Psychonomic Science, 1971, 23, 113-114.

ATTNEAVE, F. (University of Oregon, Eugene, Oreg. 97403), \& OLSON, R. K. Pitch as a medium: A new approach to psychophysical scaling. Americal Journal of
Psychology, 1971, 84, 147-166.

CAIN, W. S. (Yale University, New Haven, Conn. 06520), \& STEVENS, J. C. Effort in sustained and phasic handgrip contractions. American Journal of Psychology, 1971, 84, 52-65.

GIPS, J. (Unit on Psychophysiology, Laboratory of Psychology, National Institute of Mental Health, Bethesda, Md. 20014 ), P F E F F R B A U M, A., \& BUCHSBAUM, M. ERL-A language for implementing evoked response and psychophysiological experiments. Behavior Research Methods \& Instrumentation, 1971, 3, 199-201.

MELLERIO, J. (Department of Physiological Optics, Institute of Ophthalmology, Judd Street, London WC1H 9QS, England). Light absorption and scatter in the human lens. Vision Research, 1971, $11,129-141$.
MO, S. S. (University of Detroit Detroit, Mich. 48221). Judgment of temporal duration as a function of numerosity. Psychonomic Science, 1971, 24, 71-72.

NEWMAN, C. V. (University of Birmingh am, Birmingham, England). The influence of visual texture density gradients on relative distance judgements. Quarterly Journal of Experimental Psychology, 1971, 23, 225-233.

REGAN, D. (Department of Communication, University of Keele, Keele, Staffordshire, England), \& TYLER, C. W. Wavelength-modulated light generator. Vision Research, 1971, 11, 43-56.

ROSENBERGER, P. B. (Box C, Waverly, Mass. 02178), \& ERNEST, J. T. Behavioral assessment of absolute visual thresholds in the albino rat. Vision Research, 1971, 11, 199-207. 


\section{CURRENT LITERATURE ON HUMAN HEARING}

BERNSTEIN, I. H. (University of Texas at Arlington, Arlington, Tex. 76010), \& CLARK, M. H. Intersensory effects in the psychological refractory period. Perception \& Psychophysics, 1971, 9, 135-139.

d'ANGLEJAN, A. (McGill University, Montreal 110, P.Q., Canada), LAMBERT, W. E., \& TUCKER, G. R. Psychological correlates of the French sound system. Perception \& Psychophysics, 1971, 9, 356-357.

DORNBUSH, R. L. (New York Medical College, New York, N.Y. 10029). Delay of auditory input in "simulataneous" auditory and visual short-term memory. Perception \& Psychophysics, 1971, 9, 97-98.

EARLE, D. C. (University of Hull, Hull, England), \& LOWE, G. Channel, temporal, and composite uncertainty in the detection and recognition of auditory and visual signals. Perception \& Psychophysics, 1971, 9, 177-181.

EMMERICH, D. S. (State University of New York at Stony Brook, Stony Brook, N.Y. 11790). Cueing signals in auditory detection and frequency discrimination experiemnts. Perception \& Psychophysics, 1971 , 9, 129-134.

POLLACK, I. (Mental Health Research Institute, University of Michigan, Ann Arbro, (Mental Health Research Institute, University of Michigan, Ann Arbor, blocked auditory displays: Shifting block designs. Perception \& Psychophysics, 1971, 9, 335-338.

POLLACK, I. (Mental Health Research Institute, University of Michigan, Ann Arbor, Mich. 48104). Discrimination of restrictions in sequentially-encoded auditory displays: Block designs. Perception \& Psychophysics, 1971, 9, 57-60.

POLLACK, I. (Mental Health Research Institute, University of Michigan, Ann Arbor, Mich, 48104). Discrimination of restrictions upon auditory sequentially encoded information: Block parity. Perception \& Psychophysics, 1971, 9, 253-256.

POLLACK, I. (Mental Health Research Institute, University of Michigan,
Ann Arbor, Mich, 48104). Discrimination of restrictions upon auditory sequentially encoded information: Block parity. Perception \& Psychophysics, 1971, 9, 253-256.

POLLACK, I. (Mental Health Research Institute, University of Michigan, Ann Arbor, Mich. 48104). Discrimination of restrictions upon sequentially encoded information: Variable length periodicities. Perception \& Psychophysics, 1971, 9, 321-326.

POLLACK, I. (Mental Health Research Institute, University of Michigan, Ann Arbor, Mich. 48104). Methodological examination of the PEST (parametric estimation by sequential testing) procedure: II. Perception \& Psychophysics, 1971, 9, 229-230.

WARREN, R. M. (University of Wisconsin, Milwaukee, Wis. 53201), \& OBUSEK, C. J. Speech percpetion and phonetic restorations. Perception \& Psychophysics, 1971, 9, 229. 230 .

\section{CURRENT LITERATURE ON SIGNAL DETECTION}

BANKS, W. P. (Pomona College, Claremont, Calif. 91711) Confidence-rated recall, $d_{r}$, and tests of Bermbach's finite-state the or: in recall. Psychological Bulletin, 1971, 76, 151-152.

BER NBACI, H. A. (Cornell University, Ithaca, N.Y. 14850). Invariance of $d^{*}$ in memory: response to Banks. Psychological Bulletin, 1971, 76, 149-150.

CLEMENT, D. E. (University of South Florida, Tampa, Fla. 33620), \& HOSKING, K. E. Scanning strategies and differential sensitivity in a visual signal detection task: Intrasubject reliability. Psychonomic Science, 1971, 23, 323-324.

CLEMENT, D. E. (University of South Florida, Tampa, Fla. 33620), \& SCHIERECK, J. J. Scanning strategies and differential sensitivity in a visual signal detection task: Intersubject consistency.
Psychonomic Science, 1971, 23, 385-387.

ELY, D. J. (Porterville State Hospital, Porterville, Calif. 23257). A comment on the Yaremko, Blair, and Leckart report: "The orienting reflex to changes in a conceptual stimulus dimension." Psychonomic Science, 1971, 23, 414.

PASTORE, R. E., \& SORKIN, R. D. (Purdue University, Lafayette, Ind. 47907). Adaptive auditory signal processing. Psychonomic Science, $1971,23,259-260$.

SAXON, S. A. (Center for Developmental and Learning Disorders, University of Alabama, Birmingham, Ala. 35233), \& DAHLE, A. J. Auditory threshold variations during periods of induced high and low heart rates. Psychophysiology, $1971,8,23 \cdot 19$.

SEGAL, S. J. (Center for Research in Cognition and Affect, City University of New York,
33 West 42 St., New York, N.Y. 10036), \& FUSELLA, V. Effect of images in six sense modalities on detection of visual signal from noise. Psychonomic Science, 1971, 23, 55-56.

SWESSON, R. G. (Bell Telephone Laboratories, Inc., Holmdel, N.J. 07733), \& EDWARDS, W. Response strategies in a two-choice reaction task with a continuous cost for time. Journal of Experimental Psychology, 1971, 88, 67-81.

WADE, N. J. (University of Dundee, Dundee, Scotland), \& SCHUंNE, H. The influence of force magnitude on the perception of body position. I. Effect of head posture. British Journal of Psychology, 1971, 62, 157-163.

YAREMKO, R. M. (San Diego State College, San Diego, Calif. 92115). Reply to Ely. Psychonomic Science, 1971, 23, 414-415. 
DELPRATO, D. J. (Eastern Michigan University, Ypsilanti, Mich. 48197), \& HUDSON, R. L. Association by contiguity: Clustering in free recall. Psychonomic Science, 1971, 22, 98-99.

FUCHS, A. H. (Bowdoin College, Brunswick, Maine 04011). Response latency and serial position in short-term memory. Psychonomic Science, 1971, 22, 75-76.

FULKERSON, F. E. (Western Mlinois University, Macomb, Ill. 61455), \& JOHNSON, J. E. Methodological variables in verbal discrimination learning. Psychonomic Science, $1971,22,68-69$.

HYMAN, L. M. (Michigan State University, East Lansing, Mich. 48823). The effects of irrelevant dimensions and stimuli on two-choice discrimination learning by children. Psychonomic Science, 1971, 22, 249-250.

JOHN, I. D. (University of Adelaide, Adelaide, South Australia 5001). The role of unbalanced probabilities of occurrence in the identification of elementary auditory displays. Psychonomic Science, 1971, 22, 96.97.

MUELLER, J. H. (University of Missouri, Columbia, Mo. 65201), JABLONSKI, E. M., \& WEINBACH, $J$. Correction procedures in $\mathrm{A}-\mathrm{Br}$ transfer: Error elimination? Psychonomic Science, 1971, 22, 105-107.

OLSON, C. L. (Waterloo Lutheran University, Waterloo, Ontario, Canada). The magnitude of sensory preconditioning as a function of the time interval between stimulus onsets. Psychonomic Science, 1971, 22, 117-118.

RABIN OWITZ, F. M. (Tulane University, New Orleans, La. 70118), KRONFIELD, D. B., \& CAMPIONE, J. C. Stimulus alternation and continuous short-term memory in young children. Psychonomic Science, 1971, 22, 99-100.

REITZ, W. E. (University of Western Ontario, London, Ontario, Canada). Personal reinforcement and awareness. Psychonomic Science, 1971, 22, 243-245.

ROWE, E. J. (University of Western Ontario, London 72, Ontario, Canada), \& PAIVIO, A. Discrimination learning of pictures and words. Psychonomic Science, $1971,22,87-88$.

SLAYTON, A. J. (University of South Carolina, Columbia, S.C. 29208), \& BLACK, R. W. Effects of knowledge of results and amount of stimulus change on "resistance to extinction" on a perceptual motor task. Psychonomic Science, 1971, 22, 111.112.

WITTER, D. W., MUELLER, J. H., \& MARX, M. H. (University of Missouri, Columbia, Mo. 65201). Correction procedures in observational learning. Psychonomic Science, 1971, 22, 94-95.

YELEN, D. R. (Washburn University, Topeka, Kans. 66621). The effects of percent of association on discrimination shifts. Psychonomic Science, 1971, 22, 253-254.

\section{CURRENT LITERATURE ON HUMAN DISCRIMINATION LEARNING}

BERMAN, P. W. (Pennsylvania State University, University Park, $\mathrm{Pa}$. 16802), \& MYERS, J. Effects of ratio of win-stay to lose-shift problems on children's performance on win-stay problems. Psychonomic Science, 1971, 23, 131-132.

BOYER, W. N. (Colorado State University, Fort Collins, Colo. 80521), BULLOCK, M., \& VINEY, W. Effect of stimulus variation upon reversal shift performance of kindergarten children. Psychonomic Science, 1971, 23, 166-167.

CALEF, R. S. (West Virginia Wesleyan College, Buckhannon, W. Va. 26201), CALEF, R. A. B., BONE, R. N., THOMAS, T. A., \& FOX, P. A. A human analogue of dis crimination contrast. Psychonomic Science, 1971, 23, 191-192.

HARRIS, L. (Michigan State University, East Lansing, Mich. 48823), \& ALLEN, T. The effects of stimulus alignment on children's performance in a conservation of length problem. Psychonomic Science, 1971, 23, 137-139.

HINES, G. H. (Falcon Management Consultants Ltd., 10 Dryden Chambers, 119 Oxford Street, London W1R, 1PA, England). Effectiveness of social and nonsocial reinforcers in a probability learning task. Psychonomic Science, 1971, $23,411-413$.

LeBOW, M. D. (University of Manitoba, Winnipeg, Manitoba, Canada), \& TRITT, J. In t r a d i mensional and extradimensional shifts using a total change design with word stimuli. Psychonomic Science, 1971, 22, 325-327.

MACKAY, C. K. (University of Aberdeen, Aberdeen AB9 2UB, Scotland), \& BROWN, J. A learning strategy in normal children and severely subnormal adults. Psychonomic Science, 1971, 23, 391-392.

MORRIS, C. J. (Denison University, Granville, Ohio 43023 ). Electroencephalographic and evoked potential correlates of reaction time and visual discrimination performance. Psychonomic Science, 1971, 23, 193-195.

MUELLER, J. H. (University of Missouri, Columbia, Mo. 65201), JA B L ONSKI, E. M., \& FULKERSON, F. E. Clustering in free recall following verbal-discrimination learning. Psychonomic Science, 1971, 23, 163-165.

NORTON, G. R. (University of Winnipeg, Winnipeg 2, Manitoba,
Canada), MULDREW, D., \& STRUB, H. Feature-positive effect in children. Psychonomic Science, 1971, 23, 317-318.

OF F ENBACH, S. I. (Purdue University, $W_{\text {est }}$ Lafayette, Ind. 47907 ). Studies of children's probability learning behavior: VIII. Effect of punishment at two grade levels. Psychonomic Science, 1971, 23, 407-408.

VIESTI, C. R, JR. (University of Victoria, Victoria, British Columbia, Canada). Effect of monetary rewards on an insight learning task. Psychonomic Science, 1971, 23, 181-183.

WARD, L. C. (Murray State University, Murray, Ky. 42071), \& SIEGEL, P. S. Effects of delay of reinforcement and stimulus meaningfulness on the discrimination learning of retardates at two intelligence levels. Psychonomic Science, 1971, 23, 395-396.

WINEFIELD, A, H, (University of Adelaide, Adelaide, Australia), \& JEEVES, M. A. The effect of overtraining on transfer between tasks involving the same stimulus dimension. Quarterly Journal of Experimental Psychology, 1971, 23, 234-242. 


\section{CURRENT LITERATURE ON HUMAN DISCRIMINATION LEARNING}

BOWER, T. G. R. (University of Edinburgh, Scotland), BROUGHTON, J. M., \& MOORE, M. K. Infant responses to approaching objects: An indicator of response to distal variables. Perception \& Psychophysics, 1971, 9, 193-196.

CAVANAGH, J. P., \& CHASE, W. G. (Carnegie-Mellon University, Pittsburgh, $\mathrm{Pa}$. 15213). The equivalence of target and nontarget processing in visual search. Perception \& Psychophysics, 1971, 9, 493-495.

FISCHER, G. J. (Washington State University, Pullman, Wash. 99163). Sum of event probabilities and subjective estimates of pi in probability learning. American Journal of Psychology, 1971, 84, 180-184.

FLOWERS, J. H. (Yale University, New Haven, Conn. 06510), \& GARNER, W. R. The effect of stimuius element redundancy on speed of discrimination as a function of state and process limitation. Perception \& Psychophysics, 1971, 9, 158-160.

LEVINE, M. (State University of New York at Stony Brook, Stony Brook, N.Y. 11790). Hypothesis theory and nonlearning despite ideal S-R-reinforcement contingencies. Psychological Review, 1971, 78, $130-140$.

NATALICIO, L. F. S. (University of Texas at Austin, Austin, Tex. $78712), \quad \& \quad \mathrm{KIDD}, \mathrm{R}$. V. Experimental methodology and theory-building in mathematical psychology. Psychological Reports, 1971, 28, 43-54.

RADTKE, R. C. (Southern Dlinois University, Carbondale, IIl. 62901), \& JACOBY, L. Pronunciation and $n$ umber of alternatives in verbal-discrimination learning. Journal of Verbal Learning \& Verbal Behavior, 1971, 10, 262-265.
REBER, A. S. (Brooklyn College, City University of New York, Brooklyn, N.Y. 11210), \& MILLWARD, R.B. Event tracking in probability learning. American Journal of Psychology, 1971, 84, 85-99.

SAMPSON, J. R. (University of Alberta, Edmonton, Alberta, Canada), \& CHEN, I. Context effect in two-choice probability learning. Psychological Reports, 1971, 28, 65-66.

SMOTHERGILL, D. W. (Syracuse University, Syracuse, N.Y. 13210). Effects of temporal relationship between stimuli on children's discrimination learning. Perceptual \& Motor Skills, $1971,32,511-515$. STRANGE, W. (University of Minnesota, Minneapolis, Minn. 55455), \& HALWES, T. Confidence ratings in speech perception research: Evaluation of an efficient technique for discrimination testing. Perception \& Psychophysics, 1971, 9, 182-186.

\section{CURRENT LITERATURE ON VERBAL LEARNING}

ANDERSON, R. C. (University of Tllinois, Úrbana, l. 61801), \& WATTS, G. H. Response Competition in the forgetting of paired associates. Journal of Verbal Learning \& Verbal Behavior, 1971, $10,29-34$.

CAREY, P. W. (Graduate Center, City University of New York, New York, N.Y. 10036). Verbal retention after shadowing and after listening. Perception \& Psychophysics, 1971, 9, 79-83.

DIXON, P. W. (University of Hawaij, Hilo, Hawaii 96720), \& CUMMINGS, $w$. C. Effect of intertrial interval and verbal reinforcement on choice of front or back tongue position. Perceptual \& Motor Skills, 1971, 32, 59-62.

DUFFY, T. M. (University of Manitoba, Winnipeg, Manitoba, Canada), \& MONTAGUE, W. E. Sentence mnemonics and noun pair learning. Journal of Verbal Learning \& Verbal Behavior, 1971, 10, $157-162$.

DYER, F. N. (U.S. Army Medical
Research Laboratory, Fort Knox, Ky . 40121 ). Color-naming interference in monolinguals and bilinguals. Journal of Verbal Learning \& Verbal Behavior, 1971, 10, 297-302.

GUTHRIE, J. T. (Johns Hopkins University, Baltimore, Md. 21218). Feedback and sentence learning. Journal of Verbal Learning \& Verbal Behavior, 1971, 10, 23.28.

H OUCK, R. L. (Veterans Administration Hospital, Houston, Tex. 77031), \& MEFFERD, R. B., JR. Perceptual categorization: A parallel between perceptual identification and serial learning. Perceptual \& Motor Skills, 1971, 32,578 .

MADIGAN, S. A. (University of Southern California, Los Angeles, Calif. 90007), \& McCABE, L. Perfect recall and total forgetting: A problem for models of short-term memory. Journal of Verbal Learning \& Verbal Behavior, 1971, 10, 101-106.

RADTKE, R. C. (Southern nlinois
University, Carbondale, IIl. 62901), \& JACOBY, L. Pronunciation and number of alternatives in verbal-discrimination learning. Journal of Verbal Learning \& Verbal Behavior, 1971, 10, 262-265.

RUBENSTEIN, H. (Lehigh University, Bethlehem, $\mathrm{Pa}$. 18015), LEWIS, S. S., \& RUBENSTEIN, M. A. Homographic entries in the internal lexicon: Effects of systematicity and relative frequency of meanings. Journal of Verbal Learning \& Verbal Behavior, 1971, 10,57-62.

WICHAWUT, C. (University of Michigan, Ann Arbor, Mich. 48104), \& MARTIN, E. Independence of $A-B$ and $A-C$ associations in retroaction. Journal of Verbal Learning \& Verbal Behavior, 1971, 10, 316-321.

WOLLEN, K. A. (Washington State University, Pullman, Wash. 99163), \& LOWRY, D. H. Effects of imagery on paired-associate learning. Verbal Learning \& Verbal Behavior, 1971, 10, 276-284. 